\title{
Köszöntő a Hagyományok és kihívások rendezvénysorozat áttekintése tükrében
}

Kedves Vendégeink, tisztelt Résztvevők!

Az ELTE Egyetemi Könyvtár vezetőjeként magam és munkatársaim, az Egyetemi Könyvtár könyvtárosainak nevében szeretettel köszöntöm Önöket a 2016ban ötödik alkalommal megrendezett Hagyományok és kihívások címü szakmai konferenciánkon.

2011-ben, öt évvel ezelőtt indult ez a ma már rendezvénysorozatnak tekinthető konferencia, amelyen az Egyetemi Könyvtár munkatársai a világ elé, azaz a szakmai közönség elé állnak. Előadásaink célja, hogy bemutassuk azokat a fejlesztéseket és mühelymunkákat, amely az Egyetemi Könyvtár falain belül folynak, és amelyek remélhetőleg egyre szélesebb körben ismertté válnak.

Engedjék meg, hogy röviden áttekintsem eddigi rendezvényeink fontosabb témaköreit, eredményeit. Több előadó és előadás foglalkozott a már korábban megkezdett minőségfejlesztési programunk ismertetésével: bemutatásra kerültek a partneri igény- és elégedettségi mérések eredményei, a folyamatmenedzsment meghatározó tényezői, első önértékelésünk módszertana és konklúziói, valamint a minőségfejlesztési programmal párhuzamosan zajló szervezeti átalakulás kérdései, a munkamódszereink megváltozásának mozzanatai.

Az Egyetemi Könyvtári Szolgálatban (amely az ELTE könyvtárainak közössége, együttmüködése) kialakult új munkamegosztás is több szempontból tárgyalásra került.

- Közös feladatunk a minőségfejlesztésen túl a könyvtárosok felkészítése a közösen megfogalmazott célok elérésére. Az e téren tett erőfeszítéseinkről részletesen számot adtunk a kulturális szakemberek képzésére elnyert TÁMOP-pályázatunk lezárása után.

- A könyvtári rendszer az ELTE felhő szolgáltatásainak ernyője alá került, amely számos fejlesztésre adott lehetőséget.

- Az Egyetem könyvtárai új portálon, közösen jelennek meg.

- Forradalmi változás volt, hogy a korábbi felsőoktatási integráció örökségét, a széttagoltan müködő elektronikus katalógusokat közös adatbázisba szervezetük, több százezer rekordot migráltunk, javítottunk. A közös katalogizálás maga után vont számos megoldandó problémát, feladatot: több előadás foglalkozott a rekordok minőségével, a soknyelvü állomány, ezen belül a nem latin ábécét használó nyelvek dokumentumainak feltá- 
rásával, az időszaki kiadványok egységes kezelésével és feldolgozásával, az együttmüködés és az országos adatbázisoknak (például a Magyar Országos Közös Katalógusnak) való rekordátadás problémáival.

- A portál és az integrált könyvtári rendszer egyesítése szintén TÁMOP pályázati támogatással valósult meg.

- Kitértünk a szakmai közvéleményt foglalkoztató aktuális témákra, például a digitalizálás, a digitális tartalmak kezelésének kérdéskörére.

- Bemutattuk a muzeális értékü és nagy jelentőségü, mintegy 1,2 millió cédulát tartalmazó Alapkatalógusunk digitalizálását. A katalógus a portálunkról elérhető, kereshető, és első lépése volt több részből álló katalógusrendszerünk online közzétételének.

- Digitalizáltuk és feltártuk a több mint 12000 tételből álló metszetgyüjteményünket.

- Szintén több elöadásban foglalkoztunk az intézményi repozitórium, az EDIT (ELTE Digitális Intézményi Tudástár) kialakításával, fejlesztésének kérdéseivel.

- Rendezvényeink során képet kaphattak arról, hogyan kapcsolódtunk be a kutatók számára kiemelten fontos MTMT (Magyar Tudományos Múvek Tára) építésének munkálataiba.

- A könyvtárhasználók számára fejlesztett új szolgáltatásainkat is bemutattuk, amelyek közül kiemelném az online katalógusban keresett dokumentumok távoli kikérésének kialakítását.

Konferenciánkon a belső mühelymunka problémái, eredményei mellett természetesen mindig helyet kapott a történeti állomány bemutatását, illetve annak hagyományos kezelését illusztráló tudományos igényű előadás is. Azonban remélem, érzékelhető, hogy ezen a területen is szemléletet váltottunk: míg korábban a saját munkatársaink állományon végzett kutatásai álltak a középpontban, addig ma az állomány minél teljesebb, korszerübb feltárása, hozzáférhetővé és kutathatóvá tétele kerül tevékenységünk középpontjába.

Meghívott előadóink között rendszeresen szerepel a Könyvtár- és Információtudományi Intézet igazgatója, valamint kollégái, illetve az egyetem különböző szervezeti egységeinek munkatársai is, akikkel közös projekteket valósítottunk - valósítunk meg. Ez is jól mutatja, hogy az egyetem oktatási és igazgatási szervezeti egységeivel számos területen alakult ki szakmai együttmüködés, s a jó gyakorlatok széleskörủ megosztása hozzájárul a színvonalas munkavégzéshez.

Számomra, mint az intézmény felelős vezetője számára kiemelendő eredmény, hogy munkatársaim egyre nagyobb számban vállalják, hogy a nagyközönség előtt is bemutassák munkájukat, szakterületük eredményeit. Az eddigi négy konferencián tizenhárom kolléga huszonnégy előadást tartott. E rendezvényeknek is köszönhetően emelkedik a szakmai publikációk, valamint a hazai és 
a nemzetközi könyvtártudományi rendezvényekre szóló meghívásaink száma. Számos könyvtár kér tőlünk konzultációt szakmai megoldásaink megmutatására. Konferenciánkon évről évre növekedett az érdeklődők száma, és megjelent az igény, hogy kötetbe is rendezzük előadásainkat. A Hagyományok és kihívások címü rendezvényünk eredményei bizonyítják, hogy az Egyetemi Könyvtár az utóbbi években nyitottabb, befogadóbb intézménnyé vált, és ma már nem csupán hagyományai, állományának nagysága és muzeális kincsei, hanem a szakmai munka minősége okán is a magyar könyvtári rendszer egyik alappillére.

Hölgyeim és Uraim, kedves Vendégeink!

Nagy megtiszteltetés számunkra, hogy itt vannak. Köszöntöm és üdvözlöm az ágazati irányítás képviselőit, az egyetem vezetésének delegáltjait, a társszervezetek és a szakmai intézmények - egyetemi, oktatási szféra és az egyházi könyvtárak - képviselöit. Valamint itt köszönthetem számos régi és fiatalabb kollégámat is, az egyetem könyvtárosait. Köszönöm, hogy itt vannak, és alkalmunk nyílik arra, hogy a programban kitűzött szakmai beszélgetések során Önökkel közösen gondolkodjunk arról, mit és hogyan tehet a könyvtáros szakma a hazai kultúra és a felsőoktatás eredményesebb müködéséért.

KÁLÓCZI KATALIN föigazgató ELTE Eötvös Loránd Tudományegyetem Egyetemi Könyvtár 